Available online at: http://journal.unj.ac.id

Jurnal
Pensil

Journal homepage: http://journal.unj.ac.id/unj/index.php/ipensil/index

\title{
EVALUASI PROGRAM PRAKTIK KERJA LAPANGAN PROGRAM STUDI D3 TEKNOLOGI KONSTRUKSI BANGUNAN GEDUNG FAKULTAS TEKNIK UNIVERSITAS NEGERI JAKARTA
}

\section{EVALUATION OF FIELD WORK PRACTICE PROGRAM D3 BUILDING CONSTRUCTION TECHNOLOGY STUDY PROGRAM FACULTY OF ENGINEERING, UNIVERSITAS NEGERIJAKARTA}

\author{
Lenggogeni \\ Universitas Negeri Jakarta, Jalan Rawamangun Muka, Jakarta Timur, DKI Jakarta 13120, \\ Indonesia \\ lenggogeni@unj.ac.id
}

\begin{abstract}
Abstrak
Penelitian ini bertujuan untuk mengetahui kesesuaian program praktik

P-ISSN: 2301-8437

E-ISSN: 2623-1085

ARTICLE HISTORY

Accepted:

6 March 2020

Revision:

23 April 2020

Published:

7 May 2020

ARTICLE DOI: 10.21009/jpensil.v9i2.14568

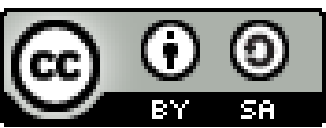
kerja lapangan pada Program Studi D3 Teknologi Konstruksi Bangunan, Fakultas Teknik, Universitas Negeri Jakarta, meliputi 1) Perencanaan, 2) Pelaksanaan dan 3) Hasil tes praktik mahasiswa dengan standar objektif. Penelitian ini juga bertujuan untuk mengetahui kendala yang dialami mahasiswa dalam pelaksanaan praktik kerja lapangan dan mengetahui hal-hal yang mendukung pelaksanaan program. Metode yang digunakan pada penelitian ini adalah model evaluasi Countenance Stake. Model ini meliputi evaluasi Antecedents, Transactions dan Ouputs. Data dalam penelitian ini berasa dari kurikulum administrasi dan responden siswa yang mengambil praktik kerja lapangan tahun 2018/2019. Berdasarkan hasil evaluasi, program ini memenuhi perencanaan dan aspek implementasi yang memenuhi standar. Pada tahap evaluasi, 62,07\% mahasiswa menerima nilai kumulatif A-. Dari jumlah tersebut, mahasiswa dapat memahami seluruh materi sebesar $81 \%$ hingga $85 \%$. Skor umpan balik adalah 4, yaitu mahasiswa memahami kompetensi khusus yang diperoleh praktik kerja lapangan.
\end{abstract}

Jurnal Pensil : Pendidikan Teknik Sipil is licensed under a Creative Commons Attribution-ShareAlike 4.0 International License (CC BY-SA 4.0).
Kata kunci: evaluasi program, magang

\section{Abstract}

This study aims to determine the appropriateness of the implementation of the internship program in the Building Construction Technology Diploma Study Program, Faculty of Engineering, Universitas Negeri Jakarta, including 1) planning, 2) implementation and 3) student practice test results with objective standards. This study also aims to determine the obstacles experienced by students in the implementation of the internship and find out things that support the implementation of the program. The method used in this research is the Countenance Stake evaluation model. This model includes the evaluation of Antecedents, 
Transactions, and Outputs. The data in this study came from the curriculum, administration, and student respondents who took an internship in 2018/2019. Based on the results of the evaluation, the program fulfills the planning and implementation aspects that meet the standards. At the evaluation stage, $62.07 \%$ of students received a cumulative grade of A-. From this amount, the participants can understand all the material by $81 \%$ to $85 \%$. The feedback score is 4 , ie, students understand the specific competencies gained during the internship.

Keywords: program evaluation, internship

\section{Pendahuluan}

Program Studi D3 Teknologi Konstruksi Bangunan Gedung Fakultas Teknik Universitas Negeri Jakarta (Prodi D3 TKBG FT-UNJ) merupakan program studi vokasi yang didirikan pada tahun 1998, bagian dari program-program studi yang ada di Universitas Negeri Jakarta. Salah satu misi yang diusung oleh Prodi D3 Teknologi Konstruksi Bangunan Gedung FT UNJ adalah menghasilkan tenaga teknisi yang terdidik dan terampil dalam pelaksanaan dan pengawasan bangunan gedung di bidang teknik sipil yang mampu berwirausaha. Dalam memenuhi misi di atas dan sesuai dengan pasal-pasal pada Permenristekdikti No. 44 Tahun 2015 mengenai ketrampilan lulusan, maka salah satu kurikulum dalam Prodi D3 TKBG FTUNJ adalah Praktik Kerja Lapangan (PKL).

Menurut Buku Panduan Akademik UNJ, Praktik Kerja Lapangan atau PKL merupakan kegiatan kurikuler yang harus ditempuh oleh mahasiswa Fakultas Teknik Universitas Negeri Jakarta. Kegiatan yang berbobot 4 sks ini, bertujuan agar mahasiswa dapat membandingkan unjuk kerja tentang pekerjaan konstruksi sipil dilapangan dengan teori dan praktik yang didapatkan serta melakukan analisa dan tindakan koreksi (Buku Panduan Akademik, 2016). Selain itu, menurut Djatnika dalam Sintawati (2014, pp. 49-64), pembelajaran berbasis pengalaman di tempat kerja sesungguhnya, akan membekali mahasiswa dengan job ready skils yang berpotensi meningkatkan employability lulusan.

Kegiatan PKL akan memberikan gambaran dan wawasan serta meningkatkan kompetensi mahasiswa Prodi D3 Teknologi Konstruksi Bangunan Gedung FT UNJ pada bidang industri konstruksi. Di samping itu, selama pelaksanaan PKL mahasiswa dapat mengaplikasikan ilmu yang diterima selama kuliah, baik teori maupun praktik, serta dapat memahami lebih jauh permalahan-permasalahan yang dihadapi pada dunia konstruksi di lapangan.

Selama berdirinya Program Studi D3 TKBG FT UNJ, belum pernah dilakukan evaluasi program PKL yang menunjukkan ketercapaian tujuan pelaksanaan program ini dan kendala yang dihadapi. Evaluasi program dibutuhkan untuk mengetahui apakah suatu program berjalan sesuai rencana dan seberapa tinggi tingkat keberhasilan dari kegiatan yang direncanakan (Arikunto \& Jabar, 2004). Model yang digunakan dalam mengevaluasi suatu program ada bermacam-macam. Salah satunya adalah model Countenance Stake.

Model Countenance Stake dikembangkan oleh Robert Stake. Menurut Fernandes dalam Arikunto (2004, p. 26), evaluasi model ini terdiri dari tiga tahapan/pase yaitu; masukan (antecedents), proses (transactions), dan keluaran/hasil (outputs/outcomes). Model ini dianggap paling sesuai digunakan dalam penelitian ini karena 
dalam model ini akan dibandingkan kondisi hasil pelaksanaan program dengan standar yang ditetapkan pada program tersebut (Arikunto \& Jabar, 2004).

Dari latar belakang di atas, maka akan dilakukan penelitian evaluasi program Praktik Kerja Lapangan Prodi D3 TKBG FT UNJ untuk mengetahui apakah pelaksanaan program PKL berjalan sesuai tujuan dalam peningkatan kompetensi mahasiswa, dan kendala-kendala yang dihadapi pada pelaksanaannya. Rekomendasi yang dihasilkan dimaksudkan untuk memperbaiki kurikulum dan meningkatkan kompetensi mahasiswa pada kegiatan PKL Prodi D3 TKBG FT UNJ.

Penelitian ini bertujuan untuk mengevaluasi program Praktik Kerja Lapangan (PKL) Program Studi D3 Teknologi Konstruksi Bangunan Gedung FT UNJ terkait dengan peningkatan kompetensi mahasiswa dan kendala yang dihadapi. Keutamaan penelitian adalah pada evaluasi program PKL Prodi D3 Teknologi Konstruksi Bangunan Gedung FT UNJ dengan menggunakan model evaluasi program Countenance Stake untuk mendapatkan gambaran dan masukan bagi program.

\section{Metode Penelitian}

Pendekatan penelitian berupa pendekatan kualitatif dan kuantitatif. Data kuantitatif pada penelitian ini akan diambil dari peserta PKL semester 109 tahun akademik 2018/2019 yang sudah menempuh ujian PKL, sementara data kualitatif berasal dari dosen pembimbing/penguji, dosen penguji, dan pihak terkait.

60 orang, jumlah dosen pembimbing/penguji adalah 8 (delapan) orang. Data lain adalah hasil nilai akhir PKL baik dari lapangan maupun dari dosen penguji. Data akan diolah dan dianalisis sesuai dengan model evaluasi program Countenance Stake.

Teknik pengumpulan data pada penelitian ini adalah dengan mengumpulkan data sekunder dari literatur berupa kurikulum dan pendukung program PKL Prodi D3 Teknologi Konstruksi Bangunan Gedung, dan data primer berupa kuesioener dan wawancara dari responden. Data yang diperoleh kemudian dianalisis secara deskriptif analitis untuk mendapatkan gambaran tentang pelaksanaan program praktik kerja lapangan di Prodi D3 Teknologi Konstruksi Bangunan Gedung FT UNJ. Model penelitian ini adalah model evaluasi program Countenance Stake yang berpatokan pada tiga tahapan pelaksanaan evaluasi. Model tersebut dapat dijabarkan sebagai berikut:

Tabel 1. Model Evaluasi Countenance Stake Program PKL Program Studi D3 Teknologi Konstruksi Bangunan Gedung

\begin{tabular}{|c|c|c|}
\hline Tahap & $\begin{array}{c}\text { Description } \\
\text { Matrix }\end{array}$ & Judgement Matrix \\
\hline $\begin{array}{l}\text { Antecedents } \\
\text { (Perencanaan) }\end{array}$ & $\begin{array}{l}\text { Perencanaan } \\
\text { Program PKL } \\
\text { Prodi D3 } \\
\text { Teknologi } \\
\text { Konstruksi } \\
\text { Bangunan }\end{array}$ & $\begin{array}{l}\text { Perencanaan Program PKL } \\
\text { Prodi D3 Teknologi } \\
\text { Konstruksi Bangunan } \\
\text { Gedung sesuai standar }\end{array}$ \\
\hline $\begin{array}{l}\text { Transactions } \\
\text { (Proses/ } \\
\text { Pelaksan aan) }\end{array}$ & $\begin{array}{l}\text { Pelaksanaan } \\
\text { Program PKL } \\
\text { Prodi D3 } \\
\text { Teknologi } \\
\text { Konstruksi } \\
\text { Bangunan }\end{array}$ & $\begin{array}{l}\text { Pelaksanaan Program PKL } \\
\text { Prodi D3 Teknologi } \\
\text { Konstruksi Bangunan } \\
\text { Gedung sesuai standar }\end{array}$ \\
\hline $\begin{array}{l}\text { Outcomes } \\
\text { (Hasil) }\end{array}$ & $\begin{array}{l}\text { Hasil evaluasi } \\
\text { kompetensi } \\
\text { pengetahuan dan } \\
\text { keahlian } \\
\text { mahasiswa } \\
\end{array}$ & $\begin{array}{l}\text { Perencanaan Program PKL } \\
\text { Prodi D3 Teknologi } \\
\text { Konstruksi Bangunan } \\
\text { Gedung sesuai } \\
\text { Standar }\end{array}$ \\
\hline
\end{tabular}

\section{Hasil Penelitian dan Pembahasan}

Tahap perencanaan merupakan tahap persiapan mahasiswa dalam melaksanakan Praktik Kerja Lapangan. Tahapan ini dapat disajikan dalam Tabel 2 sebagai berikut:

Tabel 2. Hasil Data Perencanaan PKL

\begin{tabular}{|c|c|c|c|c|}
\hline No. & Kegiatan & Ada & $\begin{array}{l}\text { Tidak } \\
\text { Ada }\end{array}$ & Keterangan \\
\hline 1 & Tujuan PKL & $\sqrt{ }$ & & $\begin{array}{l}\text { Buku Panduan PKL } \\
\text { FT UNJ tahun } 2015\end{array}$ \\
\hline 2 & $\begin{array}{l}\text { Prasyarat } \\
\text { PKL }\end{array}$ & $\sqrt{ }$ & & $\begin{array}{l}\text { Buku Panduan PKL } \\
\text { FT UNJ tahun 2015, } \\
\text { Ketentuan PKL } \\
\text { Prodi D3 TKBG FT } \\
\text { UNJ }\end{array}$ \\
\hline
\end{tabular}


Tabel 2. (Lanjutan)

\begin{tabular}{|c|c|c|c|c|}
\hline No. & Kegiatan & Ada & $\begin{array}{l}\text { Tidak } \\
\text { Ada }\end{array}$ & Keterangan \\
\hline 2 & $\begin{array}{l}\text { Prasyarat } \\
\text { PKL }\end{array}$ & $\sqrt{ }$ & & $\begin{array}{l}\text { Buku Panduan PKL } \\
\text { FT UNJ tahun 2015, } \\
\text { Ketentuan PKL } \\
\text { Prodi D3 TKBG FT } \\
\text { UNJ }\end{array}$ \\
\hline 3 & $\begin{array}{l}\text { Pendataan } \\
\text { PKL }\end{array}$ & $\sqrt{ }$ & & $\begin{array}{l}\text { Mahasiswa semester } \\
5 \text { ke atas }\end{array}$ \\
\hline 4 & $\begin{array}{l}\text { Pendaftaran } \\
\text { PKL }\end{array}$ & $\sqrt{ }$ & & \\
\hline 5 & $\begin{array}{l}\text { Penelusuran } \\
\text { Proyek } \\
\text { Konstruksi } \\
\text { Tempat } \\
\text { PKK }\end{array}$ & & $\sqrt{ }$ & \\
\hline 6 & $\begin{array}{l}\text { Pembekalan } \\
\text { PKL }\end{array}$ & $\sqrt{ }$ & & $\begin{array}{l}\text { Diadakan pada } 3 \text { Juli } \\
2019\end{array}$ \\
\hline
\end{tabular}

Tujuan PKL dicantumkan pada Ketentuan PKL Prodi D3 TKBG dan Buku Panduan PKL FT UNJ tahun 2015. Tujuan PKL juga tercantum pada Buku Pedoman Akademik Universitas Negeri Jakarta untuk tiap tahun ajaran. Tujuan PKL dibacakan dan dibicarakan pada setiap Pembekalan PKL Prodi D3 TKBG.

Sejalan dengan Tujuan PKL, begitu pula dengan prasyarat PKL. Mahasiswa disyaratkan sudah menempuh 80 sks untuk bisa mendaftar sebagai peserta PKL Prodi D3 TKBG FT UNJ (Panduan PKL FT 2015) dan syarat tambahan, sudah pernah mengambil mata kuliah Manajemen Konstruksi 1 (Ketentuan PKL Prodi D3 TKBG FT UNJ 2018).

Pendataan dan pendaftaran PKL dilakukan oleh koordinator program studi dengan langkah-langkah sebagai berikut:1) Pendataan mahasiswa yang sudah menempuh 80 sks matakuliah; dan 2) Pembuatan surat pengajuan PKL ke proyek-proyek konstruksi ke Biro Akademik, Kemahasiswaan, dan Humas UNJ dengan diketahui Koordinator Program Studi.

Pembekalan PKL bagi calon peserta PKL Prodi D3 TKBG dilakukan 1 (satu) bulan sebelum tanggal pelaksanaan PKL dan wajib dihadiri oleh seluruh peserta PKL. Pada saat pembekalan, diinformasikan syarat bangunan gedung, jumlah lantai, lokasi, jumlah kelompok dalam satu proyek konstruksi, dosen pembimbing/penguji laporan, pengamatan yang harus dilakukan, etika dan sopan santun, serta ketentuanketentuan lainnya.

Kelemahan dalam tahap perencanaan PKL Prodi D3 TKBG adalah tidak adanya penelusuran proyek-proyek konstruksi yang siap dan bersedia dijadikan tempat PKL bagi mahasiswa prodi. Hal ini menyebabkan mahasiswa harus mencari sendiri dan beberapa kali mendapatkan penolakan dari proyek dengan alasan paling utama adalah proyek sudah penuh dengan peserta PKL dari universitas lain. Kekurangan ini disebabkan karena belum adanya acuan dan kerja sama dengan perusahaan-perusahaan konstruksi di Indonesia, baik BUMN maupun swasta.

Dari hasil kuesioner mengenai umpan balik pelaksanaan PKL tergambarkan dari 58 responden bahwa kendala terbesar yang dihadapi pada tahap perencanaan pelaksanaan proyek ini adalah proses pembuatan surat dari BAKHUM UNJ. Sebanyak 44,44\% responden mengalami kesulitan dalam mengurus surat perijinan PKL dari BAKHUM. Beberapa diantaranya adalah lamanya menunggu surat selesai dan terjadi kesalahan-kesalahan penyebutan nama dan ejaan yang menyebabkan harus mengulang surat kembali.

Responden yang tidak mengalami kendala dalam pengurusan administrasi pelaksanaan PKL adalah sebesar 28,57\%, dan sisanya adalah responden yang mengalami kesulitan dengan pencarian dan penerimaan proyek tujuan PKL.

Tahap pelaksanaan pada evaluasi program PKL Prodi D3 TKBG FT UNJ meliputi pelaksanaan praktik kerja lapangan pada tempat praktik yang dapat diuraikan dalam Tabel 3 sebagai berikut :

Tabel 3. Hasil Data Pelaksanaan PKL

\begin{tabular}{llcll}
\hline No. & Kegiatan & Ada & $\begin{array}{l}\text { Tidak } \\
\text { Ada }\end{array}$ & Keterangan \\
\hline 1 & $\begin{array}{l}\text { Penerimaan } \\
\text { peserta PKL }\end{array}$ & $\sqrt{ }$ & & $\begin{array}{l}\text { Surat penerimaan } \\
\text { sebagai peserta PKL } \\
\text { dari proyek } \\
\text { konstruksi }\end{array}$ \\
& & & \\
\hline 2 & $\begin{array}{l}\text { Persiapan } \\
\text { pelaksanaan } \\
\text { tindakan }\end{array}$ & & $\sqrt{ }$ & \\
& & & \\
\hline
\end{tabular}


Tabel 3. (lanjutan)

\begin{tabular}{llcll}
\hline No. & Kegiatan & Ada & $\begin{array}{l}\text { Tidak } \\
\text { Ada }\end{array}$ & Keterangan \\
\hline 3 & $\begin{array}{l}\text { Pelaksanaan } \\
\text { tindakan }\end{array}$ & $\sqrt{ }$ & Lembar kendali PKL \\
\hline 4 & $\begin{array}{l}\text { Tindakan } \\
\text { akhir }\end{array}$ & $\sqrt{ }$ & $\begin{array}{l}\text { Penilaian dari } \\
\text { pembimbing } \\
\text { lapangan, Surat tanda } \\
\text { selesai PKL dari } \\
\text { proyek konstruksi }\end{array}$ \\
\hline 5 & $\begin{array}{l}\text { Monitoring } \\
\text { pembimbing } \\
\text { lapangan }\end{array}$ & $\sqrt{ }$ & $\begin{array}{l}\text { Lembar catatan } \\
\text { kegiatan PKL }\end{array}$ \\
\hline 6 & $\begin{array}{l}\text { Monitoring } \\
\text { pembimbing } \\
\text { Prodi D3 } \\
\text { TKBG }\end{array}$ & $\sqrt{ }$ & $\begin{array}{l}\text { Lembar konsultasi } \\
\text { bimbingan }\end{array}$ \\
& & \\
\hline
\end{tabular}

Penerimaan peserta PKL oleh proyek konstruksi dibuktikan dengan surat penerimaan peserta PKL dari pimpinan proyek tersebut kepada koordinator program studi. Surat tersebut sekaligus, biasanya berisi jadwal mulai PKL bagi mahasiswa Prodi D3 TKBG FT UNJ.

Pada bagian persiapan pelaksanaan PKL tidak terdapat data, karena memang pada dasarnya tidak ada lagi yang harus dipersiapkan ketika surat penerimaan dari proyek sudah diterima oleh prodi. Sementara pada saat pelaksanaan, evaluasi dapat dilihat dari lembar kendali yang harus dikontrol oleh koordinator program studi.

Tindakan akhir ditandai berupa evaluasi dari pembimbing lapangan/orang yang ditunjuk untuk menguji peserta PKL di lapangan, dan surat pemberitahuan bahwa mahasiswa tersebut telah selesai mengikuti PKL pada proyek yang bersangkutan. Surat ditujukan pada koordinator program studi dari pimpinan proyek konstruksi tempat PKL.

Bagian terakhir dari tahap ke dua ini adalah monitoring kegiatan PKL mahasiswa, baik dari pembimbing lapangan maupun dari dosen pembimbing/penguji di kampus UNJ. Monitoring tersebut dilakukan sesuai yang tertulis pada lembar catatan PKL untuk pembimbing lapangan di proyek konstruksi masing-masing mahasiswa. Untuk monitoring oleh dosen pembimbing/penguji di kampus, maka dicantumkan pada lembar konsultasi bimbingan setiap mahasiswa.
Berdasarkan Ketentuan Pelaksanaan PKL Prodi TKBG tahun 2018 ditentukan bahwa peserta PKL harus melaksanakan bimbingan minimal 10 kali dengan dosen pembimbing/penguji PKL di kampus yang dibuktikan pada lembar kontrol/presensi pelaksanaan PKL.

Tahap hasil (keluaran), yaitu evaluasi pelaksanaan program PKL yang meliputi hasil sidang ujian praktik kerja lapangan dan umpan balik dari peserta PKL.

Berikut ini ada grafik distribusi nilai akhir PKL mahasiswa Prodi D3 TKBG FT UNJ yang berasal dari dosen pembimbing/penguji lapangan dan dosen pembimbing/penguji di kampus UNJ.

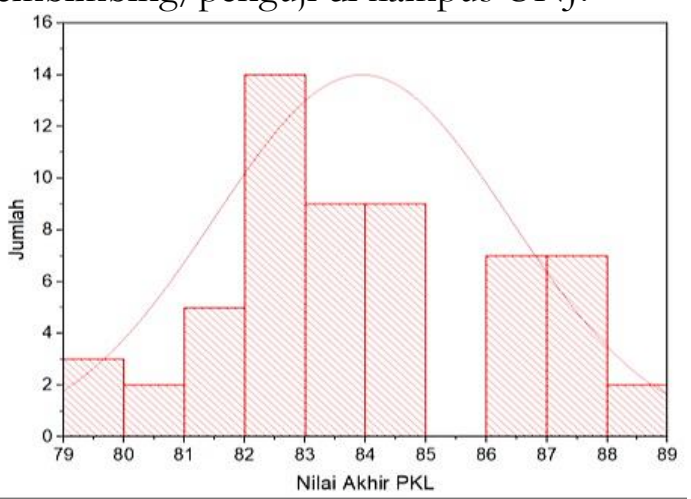

Gambar 1. Grafik nilai akhir PKL

Gambar 1 menampilkan data nilai yang diterima peserta PKL yang diberikan oleh pembimbing lapangan dan dosen pembimbing/penguji di Kampus UNJ. Persentase pembagian nilai huruf dapat ditampilkan sebagai berikut :

Tabel 4. Persentase Besaran Nilai Huruf Peserta PKL

\begin{tabular}{llc}
\hline \multicolumn{2}{c}{ Nilai } & Persentase \\
\hline A & $(86-100)$ & $27.59 \%$ \\
A- & $(81-85)$ & $62.07 \%$ \\
B+ & $(76-80)$ & $8.62 \%$ \\
B & $(71-75)$ & $1.72 \%$ \\
\hline
\end{tabular}

Dari Tabel 4 terlihat bahwa sebesar $62,07 \%$ mahasiswa mendapat total nilai Adan persentase terkecil adalah nilai B dengan persentase $1.72 \%$. Dari jumlah tersebut maka diketahui bahwa $62.07 \%$ mahasiswa peserta PKL yang telah diuji oleh pembimbing lapangan maupun dosen pembimbing/penguji kampus, dapat 
memahami semua materi PKL sebesar 81\% hingga 85\% materi PKL.

Untuk mengetahui bagaimana pemahaman kemampuan teknis mahasiswa dalam pelaksanaan PKL maka dilakukan penyebaran kuesioner yang indikatornya diambil dari Ketentuan PKL Prodi D3 TKBG FTUNJ. Adapun hasil umpan balik tersebut tergambarkan pada tabel berikut dalam persentase besarnya jawaban.

Tabel 5. Persentase kemampuan teknis peserta PKL

\begin{tabular}{|c|c|c|c|c|c|c|c|c|}
\hline \multicolumn{2}{|r|}{ Kisi-Kisi } & \multicolumn{2}{|r|}{ Butir } & \multirow{2}{*}{$\begin{array}{ll}1 \\
0 \%\end{array}$} & \multirow{2}{*}{$\frac{2}{1.6 \%}$} & \multirow{2}{*}{\begin{tabular}{|c|}
$\mathbf{3}$ \\
$12.7 \%$
\end{tabular}} & \multirow{2}{*}{\begin{tabular}{|l}
4 \\
$57.1 \%$
\end{tabular}} & \multirow{2}{*}{$\frac{\mathbf{5}}{28.6 \%}$} \\
\hline 1 & $\begin{array}{l}\text { Memahami latar belakang, } \\
\text { situasi, dan kondisi proyek } \\
\text { konstruksi }\end{array}$ & 1 & $\begin{array}{l}\text { Saya sangat mengetahui latar } \\
\text { belakang pembangunan proyek } \\
\text { tempat PKL saya. }\end{array}$ & & & & & \\
\hline & & 2 & $\begin{array}{l}\text { Saya sangat mengenal posisi dan } \\
\text { daerah proyek tempat PKL saya. }\end{array}$ & $1.6 \%$ & $4.8 \%$ & $9.5 \%$ & $25.4 \%$ & $58.7 \%$ \\
\hline & & 3 & $\begin{array}{l}\text { Saya sangat mengetahui batas-batas } \\
\text { lingkungan pada proyek tempat PKL } \\
\text { saya. }\end{array}$ & $1.6 \%$ & $0 \%$ & $15.9 \%$ & $50.8 \%$ & $31.7 \%$ \\
\hline \multirow[t]{4}{*}{2} & $\begin{array}{l}\text { Mengetahui data-data } \\
\text { umum proyek }\end{array}$ & 4 & $\begin{array}{l}\text { Saya sangat mengetahui luas dan } \\
\text { tinggi bangunan proyek tempat PKL } \\
\text { saya. }\end{array}$ & $1.6 \%$ & $1.6 \%$ & $19 \%$ & $49.2 \%$ & $28.6 \%$ \\
\hline & & 5 & $\begin{array}{l}\text { Saya sangat mengetahui data-data } \\
\text { mengenai pemilik, para konsultan, } \\
\text { dan kontraktor, pada proyek tempat } \\
\text { PKL saya. }\end{array}$ & $0 \%$ & $6.3 \%$ & $38.1 \%$ & $33.3 \%$ & $22.2 \%$ \\
\hline & & 6 & $\begin{array}{l}\text { Saya sangat mampu menghitung } \\
\text { KDB dan KLB pada proyek tempat } \\
\text { PKL saya. }\end{array}$ & $1.6 \%$ & $7.9 \%$ & $30.2 \%$ & $50.8 \%$ & $9.5 \%$ \\
\hline & & 7 & $\begin{array}{l}\text { Saya sangat mampu meng- } \\
\text { gambarkan secara lengkap siteplan } \\
\text { proyek tempat PKL. }\end{array}$ & $1.6 \%$ & $6.3 \%$ & $27 \%$ & $39.7 \%$ & $25.4 \%$ \\
\hline \multirow[t]{7}{*}{3} & $\begin{array}{l}\text { Memahami } \\
\text { administrasi proyek }\end{array}$ & 8 & $\begin{array}{l}\text { Saya sangat mampu menggambarkan } \\
\text { struktur organisasi pada proyek } \\
\text { tempat PKL saya }\end{array}$ & $1.6 \%$ & $1.6 \%$ & $33.3 \%$ & $42.97 \%$ & $20.6 \%$ \\
\hline & & 9 & $\begin{array}{l}\text { Saya sangat memahami hubungan } \\
\text { kerja masing-masing unsur organisasi } \\
\text { di proytek tempat PKL saya. }\end{array}$ & $0 \%$ & $1.6 \%$ & $41.3 \%$ & $39.7 \%$ & $17.5 \%$ \\
\hline & & 10 & $\begin{array}{l}\text { Saya sangat mengetahui tugas dan } \\
\text { tanggung jawab setiap unsur pada } \\
\text { organisasi proyek tempat PKL saya }\end{array}$ & $0 \%$ & $1.6 \%$ & $30.2 \%$ & $44.4 \%$ & $23.8 \%$ \\
\hline & & 11 & $\begin{array}{l}\text { Saya sangat memahami jenis } \\
\text { pelelangan pada proyek tempat PKL } \\
\text { saya. }\end{array}$ & $0 \%$ & $7.9 \%$ & $44.4 \%$ & $34.9 \%$ & $12.7 \%$ \\
\hline & & 12 & $\begin{array}{l}\text { Saya sangat memahami jenis } \\
\text { penjadwalan yang digunakan pada } \\
\text { proyek tempat PKL saya. }\end{array}$ & $0 \%$ & $7.9 \%$ & $44.4 \%$ & $41.3 \%$ & $6.3 \%$ \\
\hline & & 13 & $\begin{array}{l}\text { Saya sangat mampu membuat } \\
\text { laporan harian, mingguan, dan } \\
\text { bulanan dari proyek tempat PKL } \\
\text { saya. }\end{array}$ & $0 \%$ & $6.3 \%$ & $38.1 \%$ & $27 \%$ & $28.6 \%$ \\
\hline & & 14 & $\begin{array}{l}\text { Saya sangat memahami system K3 } \\
\text { pada proyek tempat PKL saya. }\end{array}$ & $1.6 \%$ & $3.2 \%$ & $19 \%$ & $44.4 \%$ & $31.7 \%$ \\
\hline \multirow[t]{2}{*}{4} & $\begin{array}{l}\text { Memahami kegiatan } \\
\text { logistik pada proyek }\end{array}$ & 15 & $\begin{array}{l}\text { Saya sangat mengetahui proses } \\
\text { pemesanan material dan alat pada } \\
\text { proyek tempat PKL saya. }\end{array}$ & $0 \%$ & $6.3 \%$ & $44.4 \%$ & $31.7 \%$ & $17.5 \%$ \\
\hline & & 16 & $\begin{array}{l}\text { Saya sangat mampu membuat berita } \\
\text { acara pembelian dan pengeluaran } \\
\text { material dan alat pada proyek tempat } \\
\text { PKL saya. }\end{array}$ & $0 \%$ & $11.1 \%$ & $47.6 \%$ & $30.2 \%$ & $11.1 \%$ \\
\hline
\end{tabular}


Tabel 5. (Lanjutan)

\begin{tabular}{|c|c|c|c|c|c|c|c|c|}
\hline \multicolumn{2}{|r|}{ Kisi-Kisi } & \multicolumn{2}{|r|}{ Butir } & \multirow{2}{*}{$\begin{array}{ll}1 \\
0 \%\end{array}$} & \multirow{2}{*}{$\frac{2}{1.6 \%}$} & \multirow{2}{*}{\begin{tabular}{|c|}
3 \\
$28.6 \%$
\end{tabular}} & \multirow{2}{*}{\begin{tabular}{|l}
4 \\
$42.9 \%$
\end{tabular}} & \multirow{2}{*}{$\begin{array}{l}\mathbf{5} \\
27 \%\end{array}$} \\
\hline 5 & $\begin{array}{l}\text { Mengenal dan mengetahui } \\
\text { alat dan peralatan yang } \\
\text { digunakan pada proyek, }\end{array}$ & 17 & $\begin{array}{l}\text { Saya mengetahui semua jenisjenis } \\
\text { alat dan peralatan pada proyek } \\
\text { tempat PKL saya. }\end{array}$ & & & & & \\
\hline & dan cara penggunaan & 18 & $\begin{array}{l}\text { Saya sangat tahu kegunaan masing- } \\
\text { masing alat dan peralatan pada } \\
\text { proyek tempat PKL saya. }\end{array}$ & $1.6 \%$ & $0 \%$ & $25.4 \%$ & $46 \%$ & $27 \%$ \\
\hline & & 19 & $\begin{array}{l}\text { Saya sangat mengetahui cara } \\
\text { menggunakan masing-masing alat } \\
\text { dan peralatan pada proyek tempat } \\
\text { PKL saya. }\end{array}$ & $1.6 \%$ & $3.2 \%$ & $23.8 \%$ & $54 \%$ & $17.5 \%$ \\
\hline 6 & $\begin{array}{l}\text { Memahami metode } \\
\text { pelaksanaan penggunaan } \\
\text { perancah di proyek }\end{array}$ & 20 & $\begin{array}{l}\text { Saya sangat mampu menjelaskan } \\
\text { metode pelaksanaan penggunaan } \\
\text { perancah tempat PKL saya. }\end{array}$ & $3.2 \%$ & $4.8 \%$ & $25.4 \%$ & $42.9 \%$ & $23.8 \%$ \\
\hline 7 & $\begin{array}{l}\text { Memahami metode } \\
\text { pelaksanaan pemasangan } \\
\text { dan pelepasan beikisting } \\
\text { pada struktur bangunan }\end{array}$ & 21 & $\begin{array}{l}\text { Saya sangat mampu menjelaskan } \\
\text { metode pelaksanaan pemasangan } \\
\text { dan pelepasan bekisting pada proyek } \\
\text { tempat PKL saya. }\end{array}$ & $3.2 \%$ & $0 \%$ & $25.4 \%$ & $46 \%$ & $25.4 \%$ \\
\hline 8 & $\begin{array}{lr}\text { Memahami } & \text { metode } \\
\text { pelaksanaan } & \text { pekerjaan } \\
\text { pembesian } & \end{array}$ & 22 & $\begin{array}{l}\text { Saya sangat mampu menjelaskan } \\
\text { metode pelaksanaan pekerjaan } \\
\text { pembesian pada proyek tempat PKL } \\
\text { saya. }\end{array}$ & $1.6 \%$ & $0 \%$ & $19 \%$ & $46 \%$ & $33.3 \%$ \\
\hline 9 & $\begin{array}{l}\text { Memahami metode } \\
\text { pelaksanaan pengecoran }\end{array}$ & 23 & $\begin{array}{l}\text { Saya sangat mampu menjelaskan } \\
\text { metode pelaksanaan pengecoran } \\
\text { beton pada tempat PKL saya. }\end{array}$ & $1.6 \%$ & $0 \%$ & $12.7 \%$ & $39.7 \%$ & $46 \%$ \\
\hline 10 & $\begin{array}{l}\text { Mampu menghitung } \\
\text { volume pekerjaan } \\
\text { komponen struktur di } \\
\text { proyek }\end{array}$ & 24 & $\begin{array}{l}\text { Saya sangat mampu menghitung } \\
\text { volume komponen struktur yang } \\
\text { menjadi pengamatan saya pada saat } \\
\text { PKL. }\end{array}$ & $1.6 \%$ & $4.8 \%$ & $20.6 \%$ & $47.6 \%$ & $25.45 \%$ \\
\hline
\end{tabular}

Hal ini diperkuat oleh umpan balik yang diterima dari responden pada penyebaran kuesioner, yang menyatakan bahwa sebagian besar pemahaman berkisar pada nilai skor 4 .

Dari Tabel 5, pada indikator pemahaman latar belakang dan situasi proyek dinyatakan bahwa sebanyak $57.10 \%$ mahasiswa memahami latar belakang pendirian proyek konstruksi tempat PKL mereka, dan hanya 1.6\% yang kurang memahami batas-batas proyek PKL.

Pada bagian indikator kedua, yaitu data-data proyek, sebesar 50.8\% mahasiswa menyatakan mampu menghitung KDB (Koefisien Dasar Bangunan) dan KLB (Koefisien Luas Bangunan).

Pada indikator administrasi proyek tempat PKL, sebesar 44.4\% mahasiswa memahami tugas dan tanggung jawab setiap bagian organisasi yang terlibat dalam pelaksanaan proyek, dan dengan jumlah persentase yang sama, mahasiswa memahmi system dan pelaksanaan K3 pada proyek tempat PKL.

Selanjutnya ada 54\% mahasiswa yang memahami cara menggunakan alat-dan peralatan di proyek PKL mereka. Untuk kemampuan perhitungan volume pekerjaan, $47 \%$ mahasiswa peserta PKL menyampaikan bahwa mereka mampu menghitung volume pekerjaan di proyek, sementara $27 \%$ nya menyatakan sangat mampu menghitung volume pekerjaan proyek.

Berdasarkan Tabel 5 dan didukung oleh data pada Gambar 1 dapat dianalisis bahwa pemahaman mahasiswa terhadap materi pelaksanaan PKL masih belum mencapai maksimal. Hal ini terlihat dari nilai A- yang paling banyak di dapat, dan pernyataan peserta yang berkisar di skor 4 . Belum maksimalnya nilai dan pemahaman mahasiswa pada proses pelaksanaan PKL 
dapat disebabkan karena kurangnya pengetahuan dasar mahasiswa terhadap kegiatan-kegiatan di proyek konstruksi dan kurangnya pengamatan yang dilakukan di lapangan.

Kendala dari mahasiswa pada saat pelaksanaan PKL dari hasil kuesioner umpan balik dengan presentase terbesar adalah beratnya pelaksanaan PKL karena dibarengi dengan jadwal perkuliahan semester $(18.96 \%)$. Sisa jawaban tersebar, berupa kesulitan dalam mendapatkan bimbingan dari pembimbing lapangan, kurang semangat dalam melaksanakan PKL, kesiapan fisik dan mental karena PKL dilaksanakan bersamaan dengan perkuliahan, kurangnya wawasan mengenai PKL, kurangnya waktu dalam mencari tempat PKL, dan lain-lain.

\section{Simpulan}

Berdasarkan hasil penelitian ini dapat disimpulkan sebagai berikut: Pertama, pada tahap perencanaan adalah terpenuhi semua aspek perecanaan sebelum pelaksanaan, kecuali penelusuran tempat PKL. Hal ini disebabkan oleh belum adanya acuan dan kerjasama dengan perusahaan-perusahaan konstruksi di Indonesia.

Kedua, pada tahap pelaksanaan terlihat bahwa runtutan pemberkasan, mulai dari surat ijin melaksanakan PKL pada proyek konstruksi tertentu, hingga lembarlembar monitoring lengkap dan dilaksanakan secara baik oleh mahasiswa.

Ketiga, pada tahap hasil/luaran, yang berupa evaluasi pelaksanaan PKL menghasilkan bahwa persentase nilai total mahasiswa peserta PKL adalah A- dan hasil umpan balik penilaian kemampuan mahasiswa terbanyak berada pada skor 4 yaitu mahasiswa paham mengenai kompetensi khusus yang didapat selama pelaksanaan PKL Prodi D3 TKBG FT UNJ.

\section{Daftar Pustaka}

Arikunto, S., \& Jabar, C. (2004). Evaluasi Program Pendidikan: Pedoman Teoretis Praktis Bagi Praktisi Pendidikan. Jakarta: Bumi Aksara.

Buku Panduan Akademik. (2016). Buku Panduan Akademik Universitas Negeri Jakarta. Jakarta: Universitas Negeri Jakarta.

Jumardin. (2013). Evaluasi Program Praktik. Kerja Lapangan Siswa SMK Kesehatan Persada Wajo pada Institusi Pasangan. Makassar: UPT PERPUSTAKAAN UNM. Thesis.

Mahfud, T. (2016). Evaluasi Program Praktik Kerja Lapangan Jurusan Tata Boga Politeknik Negeri Balikpapan. Jurnal Pendidikan Teknologi dan Kejuruan 23(1), 110-116.

Panduan PKL FT UNJ. (2015). Panduan Praktik Kerja Lapangan FT UNJ Tabun 2015. Jakarta: FT UNJ.

Putra, A. T. (2012). Evaluasi Program Pendidikan: "Pedekatan Evaluasi Program Berorientasi Tujuan (GoalOriented Evaluation Approach: Ralph W. Tyler)". Shautut Tarbiyah 18(1), 5568.

Sintawati, E., \& Sudjimat, D. A. (2014). Evaluasi Program Praktik Industri Mahasiswa Program Studi Tata Busana Jurusan Teknologi Industri Fakultas Teknik Universitas Negeri Malang Berdasarkan Model CIPP. Teknologi dan Kejuruan 37(1), 49-64.

Sukanti. (2005). Efektivitas Pelaksanaan Praktik Kerja Lapangan Program D3 Fakultas Ilmu Sosial Universitas Negeri Yogyakarta. Jurnal Pendidikan Akuntansi Indonesia 4(2), 38-61.

Widoyo, E. P. (2013). Evaluasi Program Pembelajaran. Yogyakarta: Pustaka Belajar. 